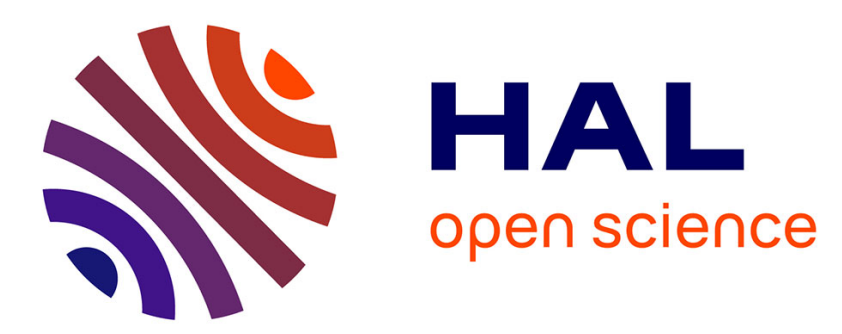

\title{
Does antimony affect microbial respiration in Mediterranean soils? A microcosm experiment
}

Frédérique Guillamot, Virgile Calvert, Marie-Virginie Millot, Steven Criquet

\section{To cite this version:}

Frédérique Guillamot, Virgile Calvert, Marie-Virginie Millot, Steven Criquet. Does antimony affect microbial respiration in Mediterranean soils? A microcosm experiment. Pedobiologia, 2014, 57 (2), pp.119-121. 10.1016/j.pedobi.2014.01.003 . hal-01802443

\section{HAL Id: hal-01802443 \\ https://hal.science/hal-01802443}

Submitted on 29 May 2018

HAL is a multi-disciplinary open access archive for the deposit and dissemination of scientific research documents, whether they are published or not. The documents may come from teaching and research institutions in France or abroad, or from public or private research centers.
L'archive ouverte pluridisciplinaire HAL, est destinée au dépôt et à la diffusion de documents scientifiques de niveau recherche, publiés ou non, émanant des établissements d'enseignement et de recherche français ou étrangers, des laboratoires publics ou privés. 


\title{
Short communication
}

\section{Does antimony affect microbial respiration in Mediterranean soils? A microcosm experiment}

\author{
Frédérique Guillamot, Virgile Calvert, Marie-Virginie Millot, Stéven Criquet* \\ Aix-Marseille Université, Faculté des Sciences et Techniques de Saint-Jérôme, Institut Méditerranéen de Biodiversité et d'Ecologie marine et continentale
} IMBE UMR CNRS 7263 IRD 237, Equipe Systèmes Microbiens, Service 441, 13397 Marseille Cedex 20, France

\section{A R T I C L E I N F O}

\section{Article history:}

Received 27 May 2013

Received in revised form 20 January 2014

Accepted 22 January 2014

\section{Keywords:}

Antimony

Metalloid

Microcosm

Respiration

Soil contamination

\begin{abstract}
A B S T R A C T
The aim of this study was to determine the effects of antimony on soil microbial respiration. Two Mediterranean calcareous soils were sampled: a contaminated soil close to an abandoned lead and silver smelter and a soil far from the pollution source and considered not to be contaminated. Two forms of antimony, antimony trioxide $\left(\mathrm{Sb}_{2} \mathrm{O}_{3}\right)$ and potassium antimonyl tartrate trihydrate $\left(\mathrm{C}_{8} \mathrm{H}_{4} \mathrm{~K}_{2} \mathrm{O}_{12} \mathrm{Sb}_{12} \cdot 3 \mathrm{H}_{2} \mathrm{O}\right)$, were tested at three concentrations $(50,500$ and $5000 \mathrm{ppm})$ in controlled conditions under short- (3 days) and medium- (3 months) term incubation. Modifications in the substrate-induced respiration (SIR) were assessed by gas chromatography respirometric measurements. Results clearly showed that SIR was immediately and significantly more affected by Sb input in a non-contaminated soil than in a long-term contaminated soil, especially since the concentration was high and Sb was added to a more soluble and available form (tartrate instead of mineral oxide).
\end{abstract}

Antimony (Sb), a metalloid of the same periodic group as arsenic (As), is known to present toxicological properties, but its effect on the environment and on human health is little documented. Worldwide production of $\mathrm{Sb}$ is considerably greater than of As, Sb having a wide range of uses (manufacture of semiconductors, diodes, flameproof retardants, lead hardener, etc.) (Filella et al. 2002). As a consequence of its extensive use, many soils have been contaminated by this metalloid worldwide, through geogenic sources or anthropogenic pollution from activities such as mining, smelting, industry and agriculture (Douay et al. 2008).

$\mathrm{Sb}$ bioavailability and toxicity depends on speciation. Sb exists at 4 degrees of oxidation: -3 and 0 , which correspond to the metallic forms abundant in the soil of shooting ranges; +3 (or $\mathrm{Sb}(\mathrm{III})$ ), the most toxic form and +5 (or $\mathrm{Sb}(\mathrm{V})$ ), the most oxidised form (Wilson et al. 2010). Although Sb and As share some chemical properties, e.g. they both occur in soils as oxides, hydroxides and oxoanions, they have so far not been shown to act in the same way. In fact, the typology of the mechanisms of Sb transport and accumulation via adsorption/desorption processes remains relatively unknown (Wilson et al. 2010). Microbial communities can play a role in Sb mobility, and thus in its availability and toxicity, via oxidation, reduction and biomethylation mechanisms (Frohne et al. 2011). Surprisingly, to date very few attempts have been made to determine $\mathrm{Sb}$ effects on soil microbial communities. Thus, the toxicity of $\mathrm{Sb}$ for soil microorganisms is relatively unknown, but appears to

\footnotetext{
* Corresponding author. Tel.: +33 4912885 30; fax: +33 491288190. E-mail address: steven.criquet@univ-amu.fr (S. Criquet).
}

vary with the degree of $\mathrm{Sb}$ oxidation. $\mathrm{Sb}$ (III) appears to be ten times more toxic than $\mathrm{Sb}(\mathrm{V})$, while methylated $\mathrm{Sb}$ appears to be the least toxic (Wilson et al. 2010).

Here, therefore, we set out to determine using microcosms the effects of various Sb molecules and concentrations on soil microbial respiration. The $\mathrm{Sb}$ (III) oxidation degree was chosen, since this form is putatively the most toxic. Two poorly vegetated soils (calcosoil with surface colluvia) were sampled on the Mediterranean coast in the Marseilleveyre Massif, Marseilles (Bouches-du-Rhône, France). The first is a contaminated soil, herein called SC, located at the former Escalette metallurgical site, which extracted lead and silver from galena until the beginning of the last century, and close to an old horizontal smokestack running up a hillside to evacuate toxic fumes $\left(43^{\circ} 13^{\prime} 30^{\prime \prime} \mathrm{N}, 5^{\circ} 20^{\prime} 54^{\prime \prime}\right.$ E Southeast of Marseilles). This smelting spread smoke, aerial deposits and metallurgical slag around the buildings, resulting in heavy metal and metalloid contamination (mainly $\mathrm{Pb}, \mathrm{Zn}, \mathrm{As}, \mathrm{Sb}, \mathrm{Cd}$ and $\mathrm{Cr}$ ). The second soil was sampled near the Sormiou creek $\left(43^{\circ} 12^{\prime} 47^{\prime \prime}\right.$ N, $5^{\circ} 24^{\prime} 58^{\prime \prime}$ E), a site far from Escalette and thus considered non-contaminated (SNC). For each station, soil samples were collected from the surface layer $(0-5 \mathrm{~cm})$ in April 2011, sieved through a $2 \mathrm{~mm}$ mesh and stored at $4{ }^{\circ} \mathrm{C}$ before use. The main physico-chemical characteristics of these soils, as well as their metal and metalloid contents, are given in Table 1.

Microcosms were prepared in plastic boxes $5 \mathrm{~cm} \times 5 \mathrm{~cm} \times 5 \mathrm{~cm}$, each containing $50 \mathrm{~g}$ of dry weight equivalent soil. Sb was supplied either as potassium antimonyl tartrate trihydrate $\left(\mathrm{C}_{8} \mathrm{H}_{4} \mathrm{~K}_{2} \mathrm{O}_{12} \mathrm{Sb}_{12} \cdot 3 \mathrm{H}_{2} \mathrm{O}\right.$, an organic highly soluble $\mathrm{Sb}$ form), herein called $\mathrm{SbT}$, or as antimony trioxide $\mathrm{Sb}_{2} \mathrm{O}_{3}$ (a mineral poorly 
Table 1

Main physical and chemical characteristics of the studied soils.

\begin{tabular}{lll}
\hline & Soil & \\
\cline { 2 - 3 } & SNC & SC \\
\hline Sand (\%) & 27.8 & 24.5 \\
Silt $(\%)$ & 34.1 & 56.7 \\
$\mathrm{Clay}(\%)$ & 38.1 & 18.8 \\
$\mathrm{pH}\left(\mathrm{H}_{2} \mathrm{O}\right)$ & 7.88 & 7.37 \\
$\mathrm{C}\left(\mathrm{g} \mathrm{kg}^{-1}\right)$ & 58.9 & 72.1 \\
$\mathrm{~N}\left(\mathrm{~g} \mathrm{~kg}^{-1}\right)$ & 3.45 & 4.4 \\
$\mathrm{C} / \mathrm{N}$ & 17 & 16.4 \\
$\mathrm{CEC}\left(\mathrm{cmol} \mathrm{kg}{ }^{-1}\right)$ & 27.2 & 16 \\
$\mathrm{As}(\mathrm{ppm})$ & 17.7 & 6348 \\
$\mathrm{Cd}(\mathrm{ppm})$ & $\mathrm{ND}$ & 38.5 \\
$\mathrm{~Pb}(\mathrm{ppm})$ & 87.4 & 38,306 \\
$\mathrm{Sb}(\mathrm{ppm})$ & $\mathrm{ND}$ & 1312 \\
$\mathrm{Zn}(\mathrm{ppm})$ & 103.6 & 11,112 \\
\hline
\end{tabular}

soluble Sb form), herein called SbO. On the basis of cartographic field measurement (data not shown) and in order to cover a wide range of concentrations, three aqueous solutions of these two compounds, with Sb concentrations of $50 \mathrm{mg} \mathrm{L}^{-1}(50 \mathrm{ppm}), 500 \mathrm{mg} \mathrm{L}^{-1}$ $(500 \mathrm{ppm})$ and $5000 \mathrm{mg} \mathrm{L}^{-1}(5000 \mathrm{ppm})$ were added to the soils to reach $60 \%$ of their water-holding capacities (WHC), yielding Sb concentrations of $6.8,68$ and $683 \mathrm{mg} \mathrm{kg}^{-1}$ of dry soil (DW). Soil microcosms without Sb were used to perform controls: (i) soils with distilled water added, termed C; (ii) to discriminate the Sb effect from the tartrate effect on SIR, soils with aqueous solutions of potassium sodium tartrate tetrahydrate $\left(\mathrm{KNaC}_{4} \mathrm{H}_{6} \mathrm{O}_{6} \cdot 4 \mathrm{H}_{2} \mathrm{O},>99 \%\right.$, Sigma-Aldrich) added, termed NaT, containing the same quantity of tartrate as SbT solutions. All microcosms were incubated in darkness at $20^{\circ} \mathrm{C}$ for 3 days (3d) or 3 months ( $\left.3 \mathrm{~m}\right)$. The lids of the boxes were perforated to allow the ventilation. The moisture content was maintained using sterile distilled water, the soil being weighted every 3 days. Five replicates were performed for each experiment and the design was completely randomised. Thus, for each incubation time ( $3 \mathrm{~d}$ and $3 \mathrm{~m}$ ), a total of 50 microcosms were realised.

Substrate-induced respiration(SIR), i.e. $\mathrm{CO}_{2}$ released when substrate is added ( $\mu \mathrm{g} \mathrm{CO}_{2} \mathrm{~h}^{-1} \mathrm{~g}^{-1} \mathrm{DW}$ ), was measured according to Anderson and Domsch (1978). Briefly, ten grams of sub-samples at $60 \%$ of their WHC were weighed in $117 \mathrm{~mL}$ glass flasks and SIR was performed by adding $50 \mathrm{mg}$ of powdered glucose to each soil sample (presumed saturating quantity; Anderson and Domsch 1978). Samples were pre-incubated for $90 \mathrm{~min}$ to reach a maximum rate of SIR. Then, after internal atmosphere replacement, flasks were closed hermetically and incubated for $60 \mathrm{~min}$ at $20^{\circ} \mathrm{C}$. The $\mathrm{CO}_{2}$ released in the flasks was measured by gas chromatography (GC, Chrompack CHROM 3 - CP 9001) and with a Porapak ${ }^{\mathrm{TM}}$ column containing $650 \mathrm{~mL} \mathrm{~h}^{-1}$ helium circulating. Mann-Whitney's tests were used to assess whether the different treatments significantly influenced respiration.
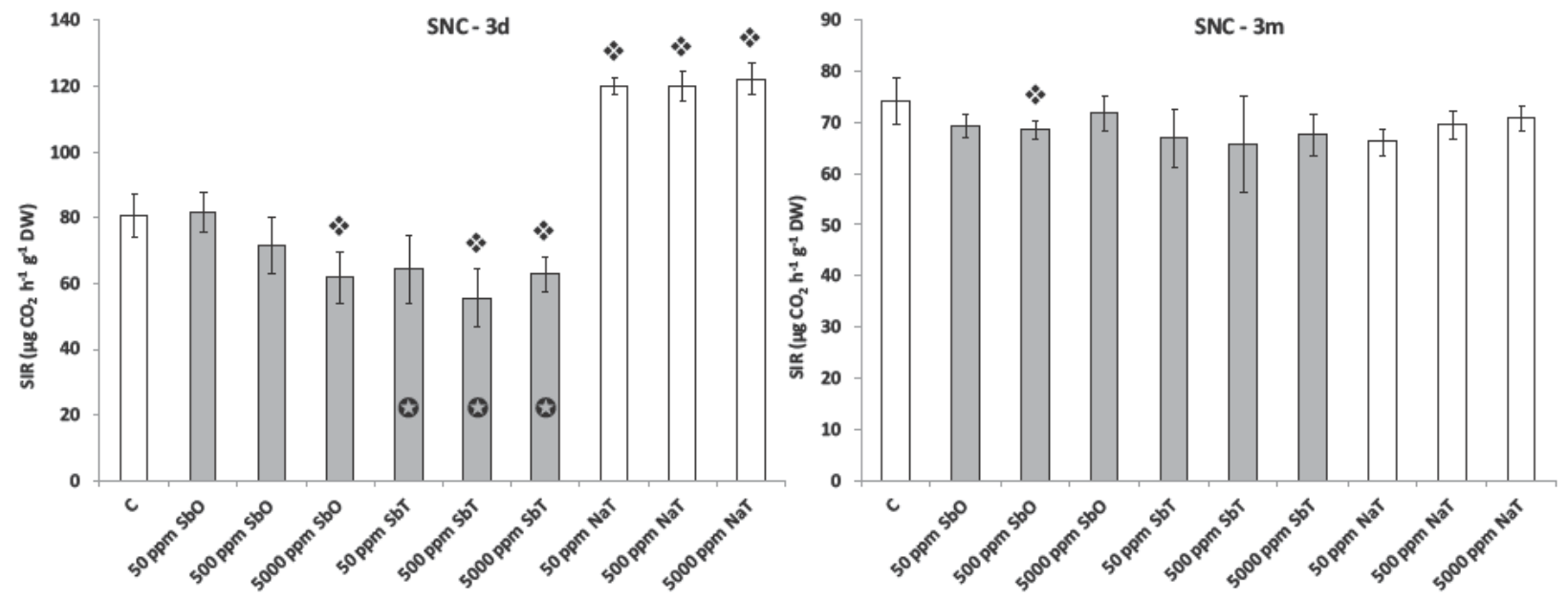

$\square$ Without Sb

$\square$ With Sb
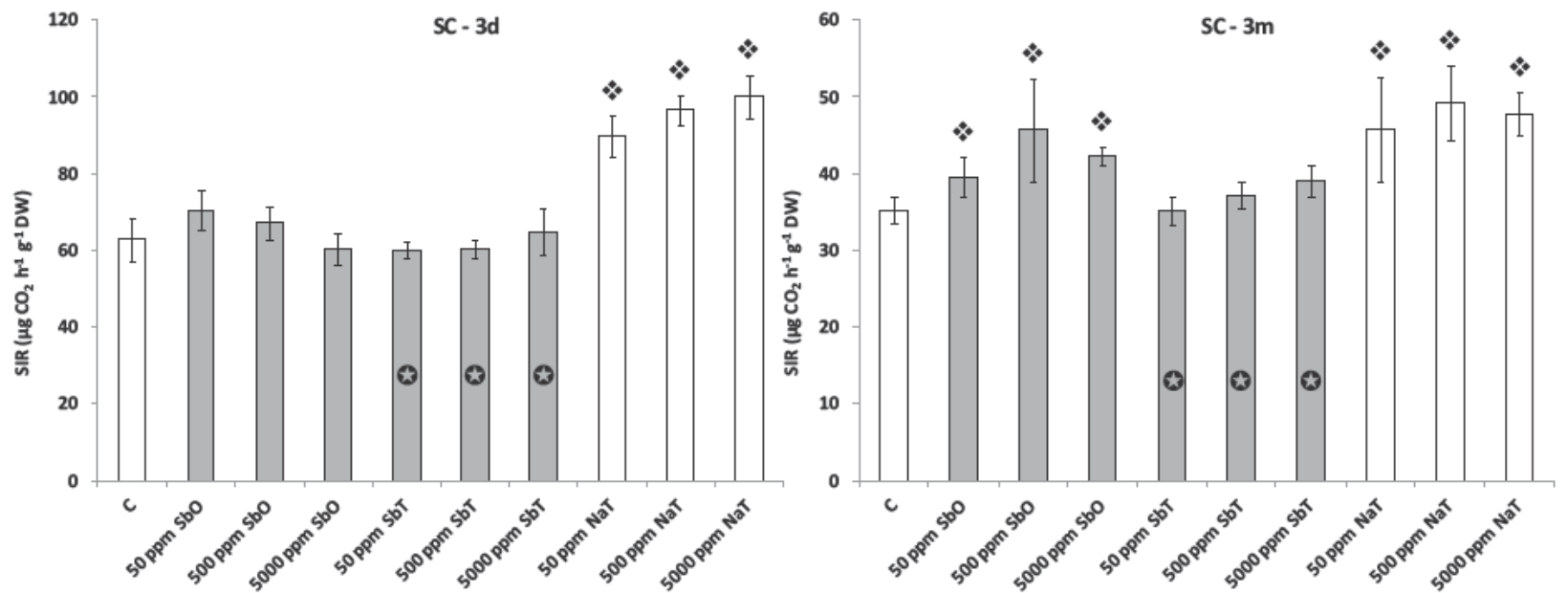

$\square$ Without Sb

$\square$ With Sb

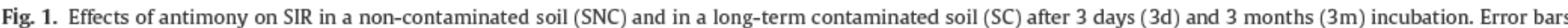

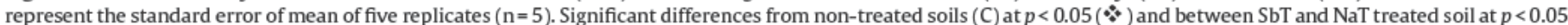

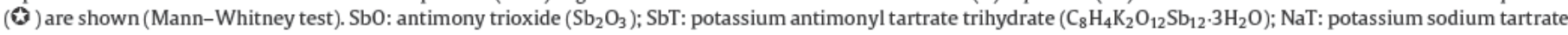
tetrahydrate $\left(\mathrm{KNaC}_{4} \mathrm{H}_{6} \mathrm{O}_{6} \cdot 4 \mathrm{H}_{2} \mathrm{O}\right)$. 
After 3-day incubation (Fig. 1), SIR was more significantly affected by $\mathrm{Sb}$ input in a non-contaminated soil than in a longterm contaminated soil, especially since the concentration was high and $\mathrm{Sb}$ was added to a more soluble and available form (tartrate instead of mineral oxide). In both soils and for both Sb forms, SIR decrease can be explained by several physiological disturbances occurring at the cell level. Sb toxicity is known to induce oxidative stress resulting in lipid peroxidation, increased membrane permeability and cell lysis by loss of cytosolic constituents. Moreover, $\mathrm{Sb}$ has the ability to substitute to $\mathrm{P}$ in biological reactions and it can also more directly affect the respiration of soil microorganisms, since it can combine with certain thiol groups of respiratory enzymes (e.g. dehydrogenases) and thus inhibit cellular energy supply (Tirmenstein et al. 1995; Shtangeeva et al. 2011). Adding the poorly soluble form of $\mathrm{Sb}, \mathrm{Sb}_{2} \mathrm{O}_{3}$, resulted, over a short-term incubation (3d), in lower SIR activities in the non-contaminated soil. This inhibition increased with the Sb dose applied, but the relation between the two variables was not proportional. Such results are consistent with those of Oorts et al. (2008) who reported that: (i) the dissolution rate of $\mathrm{Sb}$ increased almost three-fold when the applied dose of $\mathrm{Sb}_{2} \mathrm{O}_{3}$ was increased from 50 to $10,000 \mathrm{mg} \mathrm{Sb} \mathrm{kg}{ }^{-1}$; (ii) inhibition of soil respiration processes (i.e. nitrifying aerobic respiration) also occurred only at the higher dose.

After a 3-month incubation, positive effects of $\mathrm{Sb}_{2} \mathrm{O}_{3}$ occurred on SIR and remained for us unexplained. Despite this atypical response, the inhibitive effects of both $\mathrm{Sb}_{2} \mathrm{O}_{3}$ and Sb-tartrate observed at 3-d were, in most cases, nil or greatly reduced at $3-\mathrm{m}$. This could be explained by the establishment of resistance responses by microbial communities such as ATPase pumps, chemo-osmotic antiports, oxydoreduction mechanisms and intracellular or membranar retention (Rosen 2002). Surprisingly, SIR was still decreased by SbT with regards to $\mathrm{NaT}$ in the contaminated soil, whereas it was not in the non-contaminated. Since the contaminated soil had far lower clay content and CEC, another reason for the pattern observed may be due to lower $\mathrm{Sb}$ immobilisation on soil particles resulting in higher availability and toxicity towards microorganisms (Flynn et al. 2003). Despite it was not possible for us to quantify the different Sb forms, a further explanation for the decrease in toxic effects observed during our experiments could be a modification in the speciation of Sb. $\mathrm{Sb}$ (III) is known to be instable in oxic soils, and is rapidly oxidised by Fe-Mn-oxihydroxides and humic acids in its $\mathrm{Sb}(\mathrm{V})$ form, which is less toxic than the $\mathrm{Sb}$ (III) form (Oorts et al. 2008).

\section{Acknowledgements}

Financial support was provided by the French National Agency for Research (ANR) for the Marseco project headed by Isabelle Laffont-Schwob. We greatly thank the General Council of Bouchesdu-Rhône for authorising us to perform this study in the Marseilleveyre hills.

\section{References}

Anderson, J.P.E., Domsch, K.H., 1978. A physiological method for the quantitative measurement of microbial biomass in soils. Soil Biol. Biochem. 10, 215-221.

Douay, F., Pruvot, C., Roussel, H., Ciesielski, H., Fourrier, H., Proix, N., Waterlot, C., 2008. Contamination of urban soils in an area of Northern France polluted by dust emissions of two smelters. Water Air Soil Pollut. 188, 247-260.

Filella, M., Belzile, N., Chen, Y.W., 2002. Antimony in the environment: a review focused on natural waters: I. Occurrence. Earth-Sci. Rev. 57, 125-176.

Flynn, H.C., Meharg, A.A., Bowyer, P.K., Paton, G.I., 2003. Antimony bioavailability in mine soils. Environ. Pollut. 124, 93-100.

Frohne, T., Rinklebe, J., Diaz-Bone, R.A., Du Laing, G., 2011. Controlled variation of redox conditions in a floodplain soil: impact on metal mobilization and biomethylation of arsenic and antimony. Geoderma 160, 414-424.

Oorts, K., Smolders, E., Degryse, F., Buekers, J., Gasco, G., Cornelis, G., Mertens, J. 2008. Solubility and toxicity of antimony trioxide $\left(\mathrm{Sb}_{2} \mathrm{O}_{3}\right)$ in soil. Environ. Sci. Technol. 42, 4378-4383.

Rosen, B.P., 2002. Transport and detoxification systems for transition metals, heavy metals and metalloids in eukaryotic and prokaryotic microbes. Comp. Biochem. Phys. A 133, 689-693.

Shtangeeva, I., Bali, R., Harris, A., 2011. Bioavailability and toxicity of antimony. J. Geochem. Explor. 110, 40-45.

Tirmenstein, M.A., Plews, P.I., Walker, C.V., Woolery, M.D., Wey, H.E., Toraason, M.A., 1995. Antimony-induced oxidative stress and toxicity in cultured cardiac myocytes. Toxicol. Appl. Pharm. 130, 41-47.

Wilson, S.C., Lockwood, P.V., Ashley, P.M., Tighe, M., 2010. The chemistry and behaviour of antimony in the soil environment with comparisons to arsenic: a critical review. Environ. Pollut. 158, 1169-1181. 